Revista Eletrônica Geografar, Curitiba, v. 2, Resumos do VI Seminário Interno de Pós-Graduação em Geografia, p. 35-35. Junho/2007

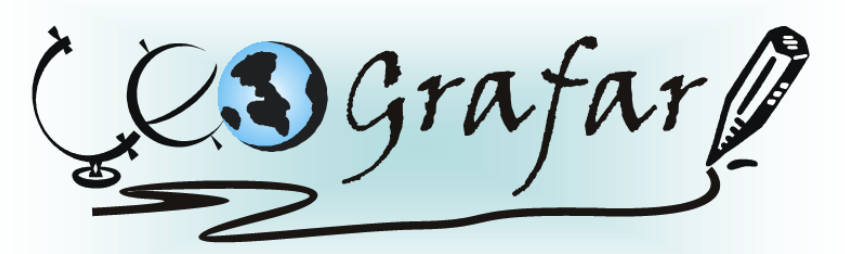

Revista Eletrônica do Programa de Pós-Graduação em Geografia - UFPR

\title{
UNIDADES DE CONSERVAÇÃO E TERRITÓRIO: CONFLITOS E CONVERGÊNCIAS NA AREA DE PROTEÇÃO AMBIENTAL DE GUARAQUEÇABA-PR
}

\section{HENRIQUE SHIGUEO UEJIMA ${ }^{1}$}

A criação de Unidades de Conservação (UC) é a principal estratégia de conservação e preservação da natureza, e possui diversas categorias. Estas últimas estão divididas em dois grandes grupos: unidades de uso sustentável e unidades de proteção integral. Uma grande maioria destas UC's possui moradores em seu interior e entorno, que embora possuem certa convergência perante a idéia de preservação, entram em conflito direto com os agentes ambientais no que diz respeito a maneira como a natureza deve ser preservada nestas áreas. Do ponto de vista do território, existem de um lado os agentes ambientais, governamentais e não-governamentais que em nome da proteção da natureza requerem o total domínio das relações de poder sobre as áreas protegidas, o que caracteriza uma territorialidade conservacionista e preservacionista. De outro lado existem as diversas populações das quais destacam-se as de cultura tradicional (transmitida através da oralidade) que foram proibidas de manter suas atividades, cujas características requerem uso e apropriação do espaço, ou seja, requerem uma territorialidade tradicional. Desde a criação do Sistema Nacional de Unidades de Conservação (SNUC), no ano 2000, e a inclusão da gestão participativa no ano de 2002, diversas são as instâncias que permitem o diálogo entre as partes requerentes dos territórios ambientais. Na realização do estudo do caso da Área de Proteção Ambiental de Guaraqueçaba-Pr, à luz dos conceitos de território, desterritorialização e reterritorialização, pretende-se como dissertação de mestrado caracterizar as duas territorialidades acima mencionadas com o objetivo de analisar as reais possibilidades e viabilidades de se buscar uma configuração multiterritorial, não pela simples superposição de distintos territórios, mas pelas interações dos conflitos e convergências existentes.

Palavras-chave: território, desterritorialização, unidades de conservação

${ }^{1}$ Mestrando em Geografia - UFPR - email:japoreto@hotmail.com

Orientador: LUIS LOPES DINIZ FILHO 